\title{
THE EFFECTIVENESS OF MOVIES AS A TEACHING LEARNING MEDIA TO IMPROVE STUDENTS' LEARNING ACHIEVEMENT AT ELEVENTH GRADE OF SMK RISE KEDAWUNG CIREBON
}

Tia Karlina

Sekolah Tinggi Ilmu Kesehatan Cirebon, Jawa Barat, Indonesia

tiakarlina20@gmail.com

\begin{tabular}{|c|c|c|}
\hline & & Abstract \\
\hline $\begin{array}{l}\text { Received: } \\
\text { Accepted: } \\
\text { Published: } \\
\text { Keywords: }\end{array}$ & $\begin{array}{l}29-01-2022 \\
29-01-2022 \\
20-02-2022 \\
\text { movies as a } \\
\text { teaching learning } \\
\text { media, students' } \\
\text { learning } \\
\text { achievement }\end{array}$ & $\begin{array}{l}\text { Learning achievement is the acquisition of knowledge or } \\
\text { skills that usually indicated by test scores in the form of } \\
\text { numerical value. By using movies to teach can definitely } \\
\text { be a challenge, but when carried out in a proper } \\
\text { manner, it boasts of numerous benefits. Unlike text, } \\
\text { movies enable students to learn visually. This research } \\
\text { aims to determine the interactive effects of movies as a } \\
\text { teaching learning media to improve students' learning } \\
\text { achievement. The researcher used experimental } \\
\text { research with quantitative approach. The sample of this } \\
\text { research was } 35 \text { respondents, randomly selected from } \\
\text { eleventh grade of SMK RISE Kedawung Cirebon. Pre- } \\
\text { experimental design was used in this research and } \\
\text { pretest and posttest design of pre-experimental design } \\
\text { became ultimate choice in this research. Based on data } \\
\text { analysis the researcher concludes that there was } \\
\text { increase of gaining score of the students after movies } \\
\text { treatment. On levels of significance o.o5, the researcher } \\
\text { found that t-observed of data is } 29.70 \text {, and the degree of } \\
\text { freedom is } 34 \text { which is converted to the t-value of } 2.03 \text {. } \\
\text { Based on the data from the test, it is clear that t- } \\
\text { observed is higher than t-value. In fact, t-observed }>\text { t- } \\
\text { value (29.7o > 2.o3), it means that the treatment of } \\
\text { movies as a teaching learning media is effective to } \\
\text { improve students'learning achievement. }\end{array}$ \\
\hline
\end{tabular}

Corresponding Author: Tia Karlina

E-mail: tiakarlina2o@gmail.com

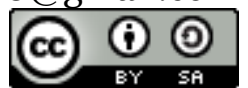

\section{INTRODUCTION}

Development of science and technology in the era globalization is very dynamic and complex in all aspects of life. As developing country, Indonesia always tries to improve its human resources. To get a good achievement for all subjects, students need perseverance and patience in learning. The researcher considers that it is necessary to find out an alternative way to create suitable and interesting techniques related to students' condition. According to (Kusumarasdyati, 2004) and (Luo, 2004) by using movies as a teaching learning media can increase the students' motivation to learn and making the class more interesting.

Movies also known as films, are type of visual communication which use moving pictures and sound to tell stories or inform (help people to learn). (Schrum, Heinich, \& Glisan, 2000) stated that movies provide the context for a wide variety of communication and interactive activities in the classroom. According to the (Brinton, 2001) various media such as video, cameras, and computers help the teacher in their job to deliver the lesson. By using the audio-visual media such as movies, the teacher can bring the world to the 
classroom. For instance, when they want to introduce names of fruits, they do not have to bring the real fruits, because the pictures of them are representative enough. A movie camera or video camera takes pictures very quickly, usually at 25 pictures every second. When a movie projector, computer, or a television shows the pictures at that rate, it looks like the things shown in the set pictures are really moving. Sound is either recorded at the same time, or added later.

Movies, in the sense of educational media, as stated by (Sudjana \& Rivai, 2005) have some strength, they are: (1) teaching and learning process will be more interesting for the students so that they are motivated to learn materials given by the teacher; (2) movies make the students easier to get the materials because media can be used by the teacher to make material easier and clearer for the students; (3) various and interesting media make the students enjoy and have fun in the learning process; (4) movies make the students do more activities in teaching and learning process. Based on the understanding that it can be concluded movies are a kind of media that contain realistic models that provide various communicative activities for the students and help the teachers to deliver the lesson.

Learning achievement is the acquisition of knowledge or skills in terms of cognitive, affective, and psychomotor through measurement and assessment. Something which achieved or done successfully of an individual or group individuals in school subject or activity with the effort and skills can be defined as the results of learning achievement (Hornby, 1989).

According to (Davis, 1993) learning outcomes are a measuring tool that used by the teacher as evidence of students' learning achievement of the material that has been given. Learning achievement is not just obtained by students, but there are several driving indicators so that learning achievement can be obtained optimally.

Nowadays, vocational education has played an important role in the Indonesian educational system for decades. The vocational education system is career-oriented, with the goal of training manpower to meet the demands of national economic growth, industrial changes, and technological advancement. From the point of view, the researcher suggests the teacher to find the most effective learning media to learn. Using movies as a teaching learning media are certainly the tool and the shortcut to help the vocational students to learn English, not only for the present but also for lifelong learning. According to (Wiyono, 2008) English at vocational school is expected that at the end of the study process, students are able to use English; they able to read, to listen, to speak, and to write in English through themes that are selected based on the students' level of development and interest.

Based on the above statements, the researcher intends to investigate the effectiveness of movies as a teaching learning media to improve students' learning achievement at eleventh grade of SMK RISE Kedawung, Cirebon.

\section{RESEARCH METHOD}

The researcher used experimental research with quantitative approach. (Sugiyono, 2019) stated that experimental research design was used to find out the influence of the certain treatment in the controlled condition. In experimental research, it is recognized at least 4 types of research and the researcher used pre-experimental design. One group pretest - posttest design of pre-experimental design became ultimate choice in this research, this kind of design tries to compare the condition of students before and after the treatments through the pretest results. They are two measured variables in this research, they are movies as a teaching learning media as the independent variable and students' learning achievement which can be seen from the test result as the dependent variable.

The population of this research is all eleventh grade students of SMK RISE Kedawung Cirebon, academic year 2021/2022, and the research held on November 1st - November 27 th 2020. The researcher takes $14 \%$ of the population as sample of this research. Technique sampling used in this study is simple random sampling. (Arikunto, 2013) stated that if the subject is less than 100 it is better to take the entire subject. Furthermore, if the subject is more than 100 it can be taken between $10-15 \%$. Therefore the researcher take 35 students randomly take from 250 students in this research. 
Tia Karlina

The Effectiveness of Movies as a Teaching Learning Media to Improve Students' Learning Achievement at Eleventh Grade of SMK Rise Kedawung Cirebon

The researcher conducted an observation dealing with the real situation of the teaching and learning process. There are two models in data analysis namely inductive and deductive data analysis technique, and the researcher using deductive data analysis technique. According to (Sidiq, Choiri, \& Mujahidin, 2019) deductive data analysis technique is data analysis that starts with theory which is then proven by facts. Starting from the determination of variables, data collection and conclusion. Here are the research instruments that used in this research are: pre-test, treatments, and post-test. Pre-test is given before the treatment of movies is carried out. The treatment of movies was carried out after pre-test. Post-test will be given after the treatment of movie is carried out.

\section{RESULTS AND DISCUSSION}

\section{Students' Learning Achievement before Using Movies}

Pretest was conducted to find out the students' learning achievement before the treatment of movies. The following tables shows the statistical description of the test result:

Table 1. Students' Learning Achievement before Using Movies

\begin{tabular}{llr}
\hline & & \multicolumn{2}{r}{ Pre-test } \\
\hline $\mathrm{N}$ & Valid & 35 \\
\cline { 2 - 3 } & Missing & $\mathrm{O}$ \\
\hline Mean & & 49.43 \\
\hline Minimum & 30 \\
\hline Maximum & & 60 \\
\hline
\end{tabular}

From the fact above, the researcher identified that none of the students fulfilled passing grade for this test. The passing grade for any subject in SMK RISE Kedawung Cirebon is 65 . This condition shows that the students learning achievement is very low. Next, the researcher found the facts concerning the cause of students low achievement that could be explained as follows: (1) low attention of the students when teaching learning process conducted; (2) almost of the students did non-academic activities rather than academic activities; (3) most of the students were passing during teaching learning process, they did not want to ask to the teacher when they had difficulty.

\section{Movies Treatment Result Analysis}

1. Treatment 1

In this meeting, the teaching learning process ran smoothly enough. First step, the researcher stimulated students interest about the topic they would learn at that day by giving some questions orally. After that, the researcher shared the handout to the students to be read. Next, the researcher asked the students to read the handout by turns. One student had a turn to read one verse and so on. Finally, they had to answer the questions that contained in the handout.

\section{Treatment 2}

In this meeting, the teaching learning process ran good better. In treatment 2 , the researcher found some progress especially concerning the movies treatment: (1) the students did not stop discussing the subject they have been learned from the movies; (2) the students also seemed were able to do their task dealing with making the summary of the movies they had just watched.

3. Treatment 3

In this meeting, the teaching learning process ran very well. In treatment 3 , the researcher found some progress especially concerning the micro skills: (1) the students were able to define what the subject they have been learned about; (2) the students were able to identify the explicit information of the subject they have been learned; (3) the students were able to identify the implicit information of the subject they have been learned.

\section{Students' Learning Achievement after Using Movies}


Tia Karlina

The Effectiveness of Movies as a Teaching Learning Media to Improve Students' Learning Achievement at Eleventh Grade of SMK Rise Kedawung Cirebon

In this research, post-test was conducted to find out the students learning achievement improvement after using movies treatment. The following table shows statistical description of the test result:

Table 2. Students' Learning Achievement after Using Movies

\begin{tabular}{llr}
\hline & & \multicolumn{2}{c}{ Post-test } \\
\hline \multirow{2}{*}{$\mathrm{N}$} & Valid & 35 \\
\cline { 2 - 3 } & Missin & $\mathrm{o}$ \\
\hline Mean & $\mathrm{g}$ & 79.43 \\
\hline Minimum & & 75 \\
\hline Maximum & & 90 \\
\hline
\end{tabular}

From the data above, the researcher conclude that there was increase of gaining score of the students after movies treatment. It was shown by the increase in mean score of posttest. The mean of pre-test was 49.43 , and the mean of post-test was 79.43 . It meant that there was increase of 30 in post-test.

\section{The effectiveness of Movies Treatment}

(Crowl \& Louvar, 2001) stated that if the value is statistically significant, it is first necessary to determine how many degrees of freedom (df) there are. The $\mathrm{df}$ is determined by taking the number of pairs of subject minus. In this case, there are 35 pairs of subject. Consequently the $\mathrm{df}=35-1=34$ at the level of significance ( $\alpha$ ) 0.05 (5\%). According t-table, the conversion for $\mathrm{df}=34$ are 2.03 for a non - directional hypothesis. After analyzing the data and collecting them using one tailed t-test formula on levels of significance 0.05, the researcher found that t-observed of data above is 29.70, and the degree of freedom is 34 which is converted to the t-value of 2.03. It was based on the criteria:

1) If t-observed < t-value, HA (alternative hypothesis) is rejected.

2) If t-observed $>t$-value, HA (alternative hypothesis) is accepted.

Based on the criteria above, $t$-observed $>t$-value $(29.70>2.03)$, so the alternative hypothesis is accepted. It means that the treatment of movie is effective to improve students learning achievement. In addition, movies treatment has increased the motivation of student interest in teaching learning process.

\section{Discussion}

\section{Students' Learning Achievement before Using Movies}

Based on the test result, before the treatments by using movies, students' learning achievement was very low. The analysis of the students score shows that there is low achievement. In the pretest, the mean of students score is 49.43. Besides analyzing the test, the researcher also analyzed the non-test data. It includes observation sheet.

Based on the observation sheet which had been conducted before the researcher implemented the treatments by using movies, the researcher concluded that the students' interest was low, the students' motivation was also low. The result of observation also showed that the students were passive learners.

\section{Students' Learning Achievement after Using Movies}

Learning language successfully depends on many factors. One of the factor is interest of the learner themselves. (Munn, 1989) states that interest is an attitude favorably disposing and motivating one toward some objects, situation or idea. It relates to the activity which makes the students to be involved in language learning. All participants found that watching movies can increase their interest to learn. The students admitted that they could comprehend every subject if it is presented by movies, and all of them agrees that this experience is enjoyable.

Based on the data analysis, after implementing the treatments, the students' learning achievement was improved. The analysis of the students' score shows that there is an improvement of the students' achievement. While, in the posttest the mean of students' score 
Tia Karlina

The Effectiveness of Movies as a Teaching Learning Media to Improve Students' Learning Achievement at Eleventh Grade of SMK Rise Kedawung Cirebon

is 79.43. After analyzing the data and collecting them using one tailed t-test formula on levels of significance 0.05 , the researcher found that t-observed of data above is 29.70, and the degree of freedom is 34 which is converted to the t-value of 2.03. Having an improvement from data analysis, it means improving the students' achievement.

\section{The Effectiveness of Movies as a Teaching Learning Media to Improve Students' Learning Achievement}

Based on the explanation, it can be concluded that before the implementation of movies treatment, there were some problems in teaching learning process. First, students' interest was low. Second, the students' motivation was also low. The students often felt bored when they in teaching learning process.

In teaching English, teacher should conduct some techniques communicatively to build students' interest in learning process. Movies are close related the students' life. It provides some opportunities for students to learn. According to (Kemp, 1963) when such an audio visual material are carefully and properly used, they can: (1) increase understanding the topic; (2) add interest to a subject; (3) contribute to a desirable attitude, etc.

Related research stated that movies seems to be an effective technique in teaching learning process, because it will reduce students' anxiety to express themselves, and when the movie or film played in the classroom, the students will get interesting classroom condition (Azimah, 2017).

Therefore, it can be seen that interest is very important in education. According to the students' opinion, they felt happy during the lesson, they were able to do exercise related the subject, it is because they were interest to learn by using movies. It means that the use of movies as a teaching learning media help the students in learning achievement.

\section{CONCLUSION}

The researcher draws a conclusion as follows the students' learning achievement before using movies was low. The teacher taught them in conventional ways, such as explaining and doing the tasks on the handbook, so they often felt bored. The students' learning achievement after using movies is shown from the difference of the students' mean score between before and after the treatments. Before the treatments, the students mean score is 49.43. After the researcher gave the treatments, the students mean was improved to 79.43. From the analysis of the mean scores using t-test, it is found that at the level of significance 0.05 the t-obtained is 29.70 and t-table is 2.03. Due to t-obtained is higher than t-table, it means that there is a significant improvement in the students' learning achievement. Based on the observation conducted the use of movies as a teaching learning media is effective in teaching learning process. The students' motivation also improved. The improvement is shown from the students' attitude during the treatments. During the researcher was implementing the treatments, the students were more active and focused on the teaching learning process. They admitted that they were more interested and enjoyed joining class using this method.

\section{BIBLIOGRAFI}

Arikunto, Suharsimi. (2013). Prosedur penelitian suatu pendekatan praktik. Google Scholar

Azimah, Anis. (2017). THE USE OF ENGLISH MOVIES ON IMPROVING STUDENTS'INTEREST IN LEARNING ENGLISH AT SMP NEGERI 2 NGUNUT. JARES (Journal of Academic Research and Sciences), 2(1), 4. Google Scholar

Brinton, Michael. (2001). Instructional Media and the New Technologies of Instruction, 2nd Ed. Canada: John Wiley \& Sons. Google Scholar

Crowl, Daniel A., \& Louvar, Joseph F. (2001). Chemical process safety: fundamentals with applications. Pearson Education. Google Scholar 
Tia Karlina

The Effectiveness of Movies as a Teaching Learning Media to Improve Students' Learning Achievement at Eleventh Grade of SMK Rise Kedawung Cirebon

Davis, Barbara Gross. (1993). Collaborative learning: Group work and study teams. Tools for Teaching, 1, 147-158. Google Scholar

Hornby, A. .. (1989). Oxford Advanced Learners' Dictionary of Current English. Oxsford: Oxford University. Google Scholar

Kusumarasdyati, Kusumarasdyati. (2004). Listening, viewing and imagination: Movies in EFL classes. International Conference on Imagination and Education. Google Scholar

Luo, Jia Jen. (2004). Using DVD films to enhance college freshmen's English listening comprehension and motivation. Unpublished Master Thesis, National Tsing Hua University, Hsinchu. Taiwan, ROC. Google Scholar

Munn, Pamela. (1989). How Do Teachers Talk about Maintaining Effective Discipline in Their Classrooms?. Google Scholar

Schrum, Heinich, \& Glisan. (2000). Teaching With Movies: A Guide for Parents and Educators. United States: Harper \& Row Publisher. Google Scholar

Sidiq, Umar, Choiri, Miftachul, \& Mujahidin, Anwar. (2019). Metode penelitian kualitatif di bidang pendidikan. Journal of Chemical Information and Modeling, 53(9), 1-228. Google Scholar

Sudjana, Nana, \& Rivai, Akhmad. (2005). Media Pengajaran, bandung PT Sinar Baru Algesindo. Google Scholar

Sugiyono. (2019). Metode Penelitian Kuantitatif, Kualitatif dan R\&D. Bandung: Alfabeta. Google Scholar

Wiyono, Tri Suko Bambang. (2008). MOTIVATION, LEARNING STRATEGY, AND LEARNING ACHIEVEMENT OF THE STUDENTS AT DEPOK 2 STATE VOCATIONAL SCHOOL (SMK NEGERI 2 DEPOK) SLEMAN. SANATA DHARMA UNIVERSITY. Google Scholar 